\title{
Appraisal Analysis of Judgment of English Billboard Advertisements on
}

\author{
Roads in Batam \\ Suswanto Ismadi Megah S. ${ }^{1}$, Siti Noor Fazelah Mohd Noorh ${ }^{2}$ \\ ${ }^{1}$ University of Riau kepualaun, ${ }^{2}$ University of Tun Hussein Onn \\ Imegah76@yahoo.co.id,2snfazelahs@gmail.com
}

\begin{abstract}
This study investigates appraisal analysis of the judgment in the English boradboard advertisement on roads in Batam. This choice of judgment by leaving affect and attitude is to focus on judgment of the advertisement makers in making perspective buyers are interested to buy their products on around roads in Batam. The framework of this study by employing of appraisal theory which was firstly introduced by Martin (1996,2000, and 2003). This theory is to analyze the evaluation of judgment of English billboard on roads in Batam. The data analyzed qualitatively. Due to research can be definite as a systematic observation analysis and objectively based on theory we can get the right result from events in special design. There were 11 data found. The data found that there were 6 personal judgments and 5 moral judgments. The personal judgment is more than moral judgment than personal judgment. This study concluded that the positive personal judgment of advertisement found mostly by admiring the product.
\end{abstract}

Keywords: Appraisal, Judgment and Advertisement

\section{INTRODUCTION}

Batam is a developing and industrial city, it causes a lot of new producers race to sell their products. To win advertisement competition is needed effective way in selling, one of the way is using advertisement. Tiani (2017:256) advertisement is considered more effective strategy to get perspective buyers than promoting at mall or supermarket. Hence, promoting products by using advertisement on road is effective strategy is expected to get many perspective buyers interested to buy the marketed houses. Therefore, advertisement is very effective due to by advertising the products the perspective buyers will get good and correct products . According to Farbey (2002: 14 ) the advertising campaign is produced to achieve a purpose, to achieve what the advertiser desires, or needs. In advertising, it is all about how to attract the people. Many ways to do that, example : using beautiful models, using funny pictures, using catchy lines, using attractive colors. In making catchy line, sometimes the marketing use foreign language, people nowadays more interested with something "western influenced", and people often use the foreign language as the implied language during their conversation. The right words and interesting 
language will influence perspective buyers to buy the products. The use of language is regarded is a correct advertisement to promote the products. Tiani (2017) concludes that language used in advertisements hypothesized as having appraisal power. The framework of appraisal consists of subsystem, namely attitude, engagement and graduation. This study leaves engagement and graduation.

Theory of appraisal is a development of systemic functional linguistics (SFL) in the interpersonal meaning domain for systematizing and investigating the construal of interpersonal meanings in texts. More specifically, appraisal focuses on how speakers express feelings, how they amplify them, and how they may incorporate additional voices in their discourses (Martin, 1997, 2000; Martin \& Rose, 2003; Martin \&White, 2005). Hence, language its self is a part of system. The use of language is called metafunction in society. Besides interpersonal meaning, metafunction also concerns to ideational and textual meaning as well. Eggin (1994) explains an introduction to systemic functional linguistics that describe "Language is structured to make three main kinds of meanings simultaneously. This semantic complexity, which allows experiental, interpersonal, and textual meaning to be fused together units, is possible because is a semiotic system: a conventionalized coding system, organized as sets of choice". Thus, in the language system involves three meaning domain. Halliday (1994) says ideational, interpersonal and textual meaning.

First metafunction is ideational function to relate physical and experiential someone. In this function the social experience of a person constructed in the language. Second function is interpersonal function, it relates to speaker and attitude between writer and reader, speaker and hearer. This function is shown to social interaction, then it is realized into pro-action. Third function is textual function, it bridges ideational and interpersonal functions. White (1998) divides this appraisal theory into three aspects, namely attitude, engagement and graduation. This study focuses on attitude. The attitude is attitudinal evaluation refers utterance, verbal message, act of outside non-personal being and object. Attitude refers to the resources used to negotiate feelings, judge people's character and behavior, and evaluate the worth of things. So, the attitude consists of three types, namely; affect, appreciation, and judgment. Affect concerns of feeling of someone (buyers), 
appreciation concerns of value (products) and judgment concerns of character (perspective buyers).

a. Affect

Affect concerns to feeling, this is an evaluation in relation to feeling of readers. Evaluation describes feeling of advertisement's makers to readers through verbal message text of the English advertisement on roads in Batam, how to evaluate emotionally toward person, things , or act. Hence, the inclusion of values of affect in a text is a clear indicator of the attitudinal stance adopted by speakers and is an effective strategy for positioning listeners and for negotiating solidarity with them. Martin (2000:172) argues that when the audience shares the speakers' feelings, "a kind of bonding occurs, where they are not so prepared, the effect is alienating".

b. Appreciation

Appreciation is an evaluation toward objects cover attitude such as appreciation is aimed to television program, movie, books, drama, or feeling something. Souza (2006:243) adds that "appreciations are interpersonal resources for expressing positive and negative evaluations of objects, texts, entities, processes, and natural phenomena. While Martin \& Rose (2003:33) explain, the authors present a short list of some objects, entities, and processes which are commonly evaluated under the heading of Appreciation. Appreciation can be positive and negative toward products, objects or act. Evaluation of appreciation is more abstract, there is no right or wrong justification. This evaluation focuses on aesthetic values from the objects, for example "Rose is beautiful" in this case, the evaluation values the objects that can be appreciated as right or wrong, good or bad, it can value that naturally rose is beautiful.

c. Judgment Judgment devises is the study relates to normative values of a writer toward someone. This evaluation concerns to norm or convention in a society. According to White (2001) judgment is aimed to evaluate human beahviour in term of social norm. Judgment can be divided 
into two subsystem, namely moral judgment and personal judgment. Souza (2006:532) affirms "Judgment resources on the other hand refer to how speakers evaluate themselves and other people in terms of their character and social behavior in relation to culturally established sets of moral, legal, and personal norms".

Therefore, judgment is normative value to judge human behavior related to moral or legal, such as moral, virtuous, lewd, sinful, lascivious, innocent, unjust, fair-minded, law-abiding, murderous, cruel, brutal, dishonest. For examples She corruptly accepted money from those bidding for the contract. Judgment has two sub-system, as follows;

1) Moral Judgment

This sub-system of moral judgment refers to evaluate human behavior, such as honest and etiquette. Moral judgment consists of two types, namely; positive judgment (praise) and negative judgment (condemn).

2) Personal Judgment

This sub-subsystem of personal judgment refers to evaluation related to human's evaluation in relation to person with norms in society. Personal judgment is divided into two types, namely positive personal judgment (admire) and negative personal judgment (criticize).

\section{RESEARCH DESIGN AND METHODS}

The source of data of this research is English advertisements on roads in Batam. English billboard advertisements on roads in Batam. The Writers obtained twenty English billboards, some of these billboards is using English as the main language and some of them is using English as the implied language. Writer will use this data to do the research. Here are some of the billboard's example, the writers had captured through our camera and notes. In collecting data, taking picture and notes will be combined in this research. Sudaryanto, (1993:153) explains that this method is done to take notes text as data sources.

In this research the writers collects the data through capturing the English billboards, and identifying the words that used in these billboards. The steps in collecting the data conducted by the writers by capturing the English billboard, collect the picture of English billboards. Then the writers divided 
the billboards, based on their type of advertisement (Brand Advertising, Retail or Local Advertising, etc ).

Then the writer attempted to reveal the aspect investigated completely by describing the object condition as the way they are (fact finding) in order to analyze more easily. The steps as follows; the writers divided he billboards based on each category of advertising. Then Categorizing of the data done to get the billboards into each category, and then the writers divided into the words that contained on the billboards. Eventually the writers analyzed the words, and determining what kinds of judgment that used on each billboards.

\section{DISCUSSION}

The following discussion is organized to analyze the data found answer the questions about types of moral judgment of English Billboard Advertisements on Roads in Batam. Detailed discussion are as follows.

\section{a.Moral Judgment}

In this case, judgment may evaluate norm or human behavior in which relate to behavior convention. This judgment deals with ethics, religion, moral, and all agreed rules. In this research, the writers found judgment type of "praise" as in below:

\section{Data 1}

"Safe Our Future, Keep Batam Clean and Green "

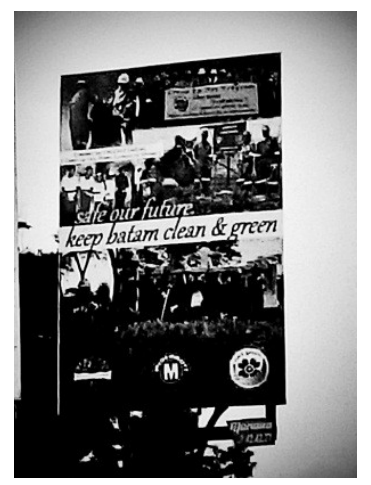

It is based on data 1 above that the clause of "Safe Our Future, Keep Batam Clean and Green " can be categorized as moral judgment due the utterances tend to be moral power to suggest that Batam city must be clean , therefore, all people who live in Batam is appealed to save Batam by clean and plant trees. The power of clause shows moral judgment power. 
Desember 2018

P-ISSN 2301-5292

E-ISSN 2598-9995

\section{Data 2}

"A Place I Call Home, Villa Panbil"

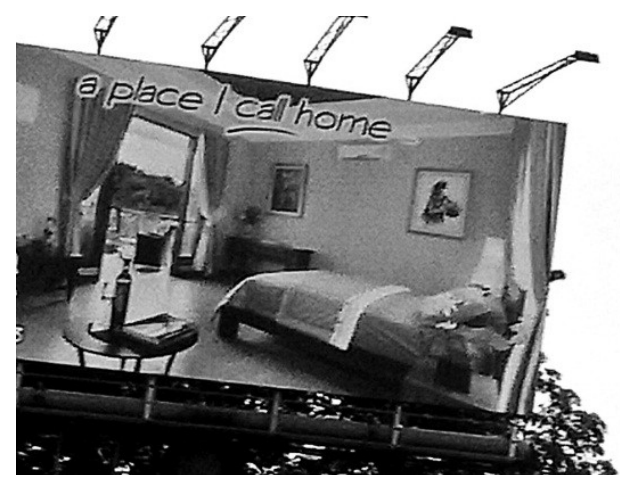

It is based on data 2 above that the clause of "A Place I Call Home, Villa Panbil" can be categorized as moral judgment due to it has aesthetic of living that the advertiser gives great image of the housing of Villa Panbil that the houses is really luxurious house for most suitable for living in the cityas like in the hill or mount calm and fresh. Therefore, if the advertiser does not use the clause as the above, so the consumers do not want to buy the house.

\section{Data 3}

“ Grand Summit South Links, An Ultimate Housing to Escape from Ordinary"

Extra line "Executive Lounge to Greet Your Guest" 
Desember 2018

P-ISSN 2301-5292

E-ISSN 2598-9995

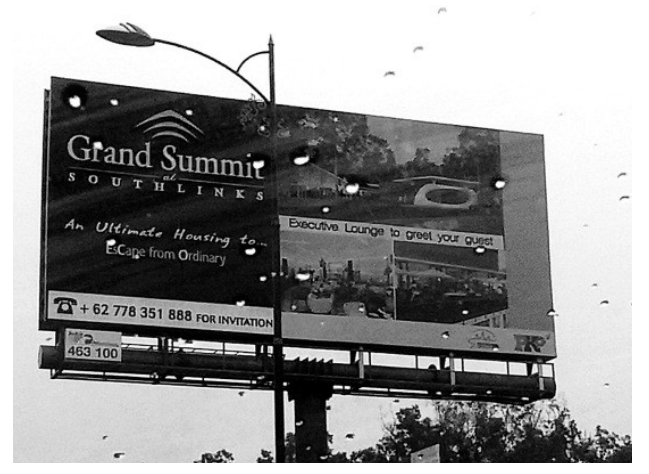

It is like the data 2 that the data 3 shows the clause of advertisement of “ Grand Summit South Links, An Ultimate Housing to Escape from Ordinary"with an extra line "Executive Lounge to Greet Your Guess" that categorized as moral judgment because it has power to praise the product that the advertiser gives an impression that the product is extra ordinary house as if you do not live as like ordinary house. This gives great impact for the perspective buyers to buy the house advertised.

\section{Data 4}

\section{“Class Mild Today's Spirit, Talk Less Do More"}

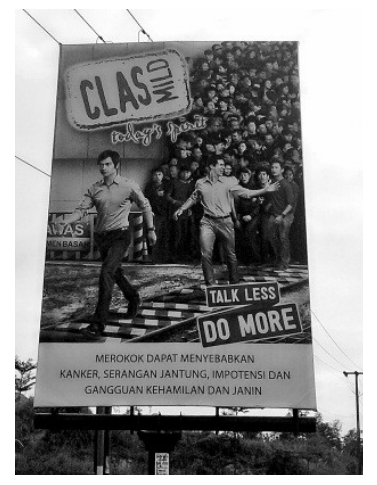

It is based on the advertisement in the data 4 that the clause of "Class Mild Today's Spirit, Talk Less Do More" is categorized as moral judgment because it has power to persuade people to have high spirit with do more the advertiser persuade people if you smoke Brand of Class Mild cigarette will work more, if you work seriously automatically you will talk less/ this shows moral judgment of spirit.

\section{Data 5}

"How Smart is your 3D ?, LG Cinema 3D Smart TV" 
The data 5 shows

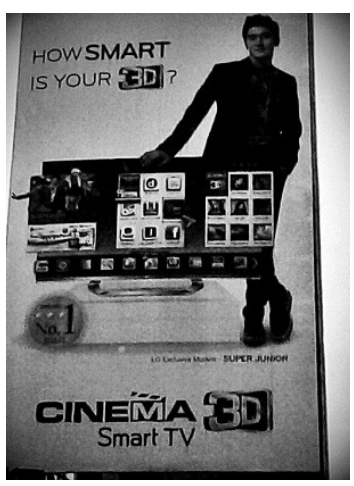

that the clause of " "How

Smart is your 3D ?, LG Cinema 3D Smart TV"

" this clause shows moral judgment due to someone who is smart to choose the product. This advertisement shows people if you choose the product the buyers are considered as smart person. This is done to praise person.

\section{b.Personal Judgment}

This personal judgment is an evaluation which is related to someone's evaluation given by individual related to norms in society. Personal judgment is divided into two subsystem positive personal judgment for instance ' admiration' and negative personal judgment for instance 'criticisms' as in following data below;

\section{Data 6}

"Speak English go make History, EF"

The data 6 above shows

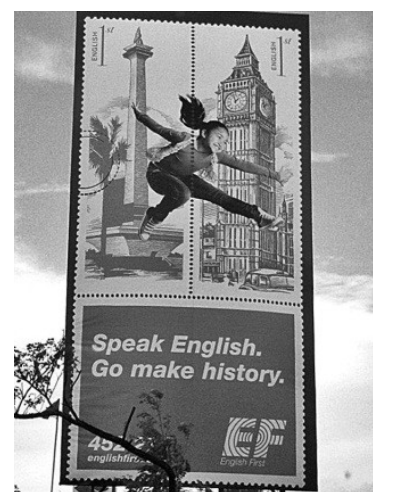

the clause of " Speak English go make History, EF" has personal judgment power due to the utterances have personal judgment by praising people. This is categorized as personal judgment because the utterances persuade people or society to make history by joining English course at EF. The words " make history “ emphasizes on the importance of speaking English to make achievement by communicating with foreigners will get much benefits. 


\section{Data 7}

"Platinum Fitness Centre, The Smartest Way to be Healthy and Strong"

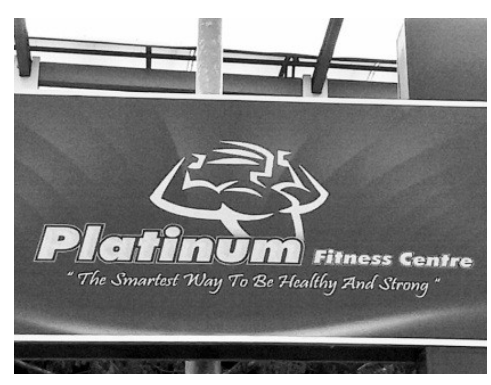

The data 7 shows that the clause of "Platinum Fitness Centre, The Smartest Way to be Healthy and Strong" is categorized as personal judgment power due to the utterances shows that fitness is a way out to be more healthier life must be undergone. The word of " the smartest way " is the best way to be healthy this admires fitness as the best way.

\section{Data 8}

"TRAC, Astra Rent a Car "

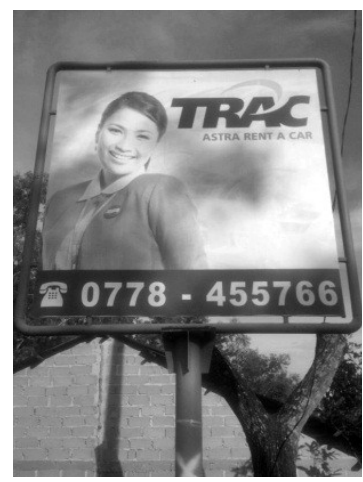

The data 9 above shows that the clause of "TRAC, Astra Rent a Car "" is categorized as personal judgment power due to the utterances shows the rent car with the picture of smiling beautiful woman. The advertisement shows how the cars rented as beautiful as the woman in the picture. This persuades people to rent the car at TRACT rent car.

\section{Data 10}

\section{"Luffman, The Taste of Satisfaction"}


Desember 2018

P-ISSN 2301-5292

E-ISSN 2598-9995

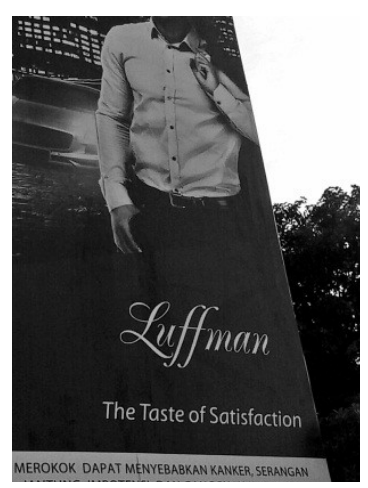

It is based on the data 10 that the clause of "Luffman, The Taste of Satisfaction" is categorized as personal judgment of admiration because the advertiser shows how Luffman as a cigarette brand admired because of its taste.

\section{Data 11}

"KepulauanAnambas, Exotisme of South China Sea Marine Park"

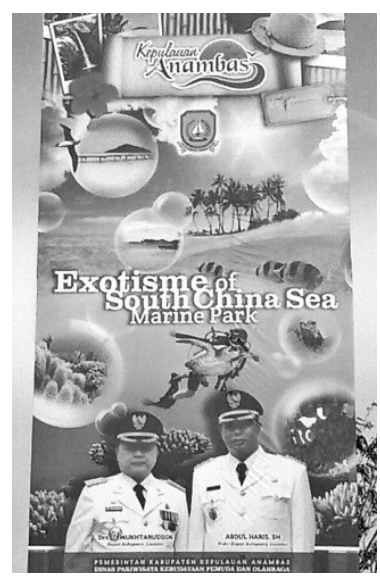

It is based on the advertisement in the data 11 that the clause “KepulauanAnambas, Exotisme of South China Sea Marine Park" is categorized as personal judgment. This evaluates that the advertiser uses the product of the anambas Islands as exotic tourism resort, this has personal judgment by admiring of the islands.

\section{CONCLUSION}


The data analyzed based on judgment of the appraisal analysis. The judgment is divided into two types; namely moral and personal judgment, it has power to analyze how the advertisements persuade people to buy the product. The data found that the advertisers used clauses with specific utterances in order the product sold out. There are 11 data found and analyzed of this study. Those are 6 personal judgments and 5 moral judgments. The personal judgment is more than moral judgment than personal judgment. The positive personal judgment of advertisement found mostly by admiring the product.

\section{REFERENCES}

Eggins, Suzanne. 1994. An Introduction to Systemic Functional Linguistics. London:Pinter Publishers.

Farbey, A D. 2002. How to Produce Successful Advertising. London : Kogan Page Ltd.

Halliday, M.A.K. . 1994. Introduction to Functional Grammar. London: Adward

Martin, J. R. 1997.Analysing genre: functional parameters. In: F.Christie \& J. R. Martin. Eds. Genre and Institutions: social processes in the workplace and school. London: Cassell.

Martin, J. R. \& D. Rose. 2003. Working with Discourse: meaning beyond the clause. London: Continuum.

Martin, J. R. \& P. R. R. White. 2005. The Language of Evaluation:appraisal in English. London: Palgrave.

Martin, JR and David Rose. 2003. Working with Discourse 'Meaning Beyond The Clause. London:Continuum.

White, P.R.R. 1998. Telling Media Tales: The News Story as Rhetoric. Unpublished research Ph.D Theses. Sydney: University of Sydney.

Souza, Anderson Alves de. 2006."The Construal of Interpersonal Meanings in the Discourse of National Anthems : An Appraisal Analysis". Proceedings33rd International Systemic Functional Congress, 2006, Universidade Federal de Santa Catarina

Sudaryanto. 1993. Metode dan Aneka Teknik Analisis Bahasa. Yogyakarta: Gadjah Mada University Press. 
ANGLO-SAXON, VOL. 9, NO.2 :157-168

Desember 2018

P-ISSN 2301-5292

E-ISSN 2598-9995

Tiani, Riris.2017.Judgment Sebagai Sistem Appraisal dalm Iklan Kecantikan Visual Media Cetak.Jurnal Nusa. Vol.12 No.4 November hal. 256-264 